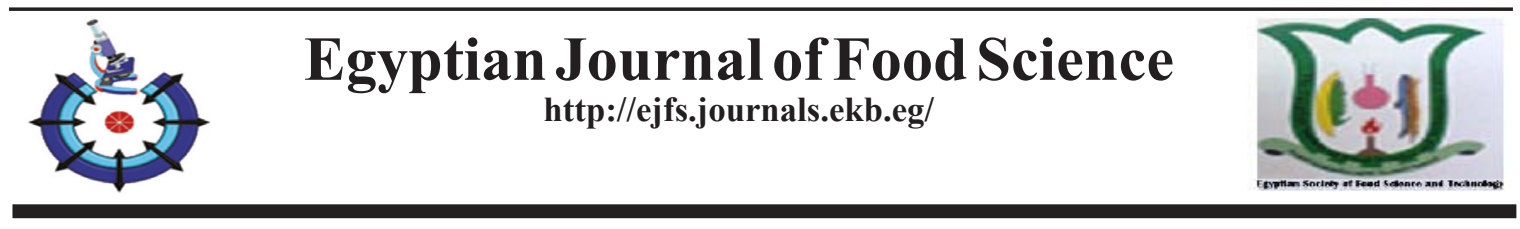

\title{
Egyptian Balady Bread Quality as Affected by Functional Nano- Powders of Some Food Industry by-Products
}

El-Sayed I. Yousif ${ }^{1}$, Attia A. Yaseen ${ }^{2}$, Abdel-Fatah A. Abdel-Fatah ${ }^{1}$, Abdel-Hafeez

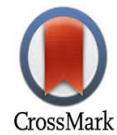

A. Shouk ${ }^{2}$, Mohamed G. Gadlla ${ }^{1}$ and Ayman A. Mohammad ${ }^{2 *}$

${ }^{1}$ Food Sci. Dept. Fac. Agric., Ain Shams Univ., Cairo, Egypt

${ }^{2}$ Food Technology Dept., National Research Centre, 33 Bohouth ST., Dokki, Cairo,

Egypt

\begin{abstract}
$\mathbf{T}$ THE USE of nano-material as delivery system in nutritional supplements is a promising technology to improve the bioavailability of their bioactive compounds. In this study, five food by-products "nano wheat bran (NWB), nano wheat germ (NWG), fermented nano-rice bran (FNRB), fermented nano-carrot pomace (FNCP) and fermented nano-pomegranate peel (FNPP)" were prepared and used as natural sources of bioactive compounds in the preparation of functional Egyptian balady bread. Nano and fermented nano-materials were used at 5, 15 and $25 \%$ replacement levels of wheat flour basis. Organoleptic characteristics, staling test and color attributes of balady bread were studied. The results of alkaline water retention capacity (AWRC) test, as a bread staling indication, revealed that all tested nano-materials showed positive effect on retarding staling of bread during storage at room temperature up to $72 \mathrm{~h}$ and the bread was better than control regarding freshness properties. The color attributes of balady bread revealed remarkable differences between control and tested samples. Addition of fiber materials significantly decreased $\mathrm{L}^{*}$ values, while $\mathrm{a}$ * values increased. Organoleptic test results showed that partially replacing of wheat flour $72 \%$ extraction by $25 \% \mathrm{NWB}, 25 \% \mathrm{NWG}, 15 \%$ FNRP, $5 \%$ of FNCP and 5\% FNPP still providing a good quality of functional Egyptian balady bread.
\end{abstract}

Keywords: Food by-products, Solid state fermentation, Nanotechnology, Balady bread quality.

\section{Introduction}

Recently, healthy nutrition has become a growing demand worldwide and thus, the production of several nutritional food products with healthy benefits. Industrial food by-products are rich sources of functional compounds for improving the nutritional value of ordinary baked products and promoting their health properties (Martins et al., 2017). Phytochemicals, vitamins, fibers and minerals among others are functional ingredients, could be prepared from cheap sources as food industries by-products (Belghith et al., 2016a and Ben Jeddou et al., 2017). The incorporation of such ingredients has technological, nutritional and health promoting impacts on baked products.
Health promoting properties of supplemented bakery products were discussed by several review articles (Ktenioudaki and Gallagher, 2012; Rawat and Indrani, 2015 and Sharma et al., 2016). Specific by-products fortification, namely wheat bran (Hemdane et al., 2016 and Onipe et al., 2015), cereal bran (Heiniö et al., 2016) and fruit pomace (Quiles et al., 2016; Derakhshan et al., 2018 and Parvin et al., 2019) were also discussed.

Food nano-technology affects the bioavailability of functional ingredients in food products and consequently its nutritional value (Srinivas et al., 2010). As recognized, the biological activities of nano-materials (including their toxicological aspects) are basically

"Corresponding author : aymnmohamed79@yahoo.com

Received :1/10/2019; accepted : 1/12/2019

DOI: 10.21608/EJFS.2019.17570.1022

C2019 National Information and Documentation Centre (NIDOC) 
dependent on their phytochemical constituents (Hwang et al., 2012 and He et al., 2015). The applicable areas of nano-technology in food industry include food security and safety aspects, extending shelf life, development of aroma and nutrient vehicles and serving functional foods (He and Hwang, 2016). At nano-scale, the structure and surface area of particles were altered bringing some new characteristics. These new characteristics (quantum, optical, magnetic, and catalytic characteristics), compared with the normal size, give the nano materials new industrial applications (Huang et al., 2007 and Zhao et al., 2009).

Available review articles are suggesting the pre-treatments of food industry by-products, such as fermentation, enzymatic heat treatments or ultra-fine grinding, that may enhance bioaccessibility of phenolics and minimize the negative effects as well as improving the health beneficial properties (Penella et al., 2008; Moore et al., 2007; Chau et al., 2007; Dordevic et al., 2010; Oliveira, 2012 and Rosa et al., 2013). Prabhu et al. (2014) evaluated the phytochemicals and antioxidant properties of rice bran fermented for 24 and $48 \mathrm{hr}$. Their results revealed that yeast fermentation significantly increased the phenolic contents by $23 \%$ and $24 \%$, flavonoid contents by $14 \%$ and $18 \%$, respectively. Yeast fermentation also decreased tannin content, which is an antinutritional factor, with about $27 \%$. Regarding antioxidant activity, fermented rice brans showed $56 \%$ and $49 \%$ radical scavenging activity and 57 and $17 \%$ total antioxidant activity with 24 and 48hr fermentation, respectively.

Balady bread is the popular type of bread among the Egyptian and Middle East consumers. Balady bread is a flat and circular loaves $(30 \mathrm{~cm}$ diameter and $1 \mathrm{~cm}$ thickness) consisting from upper (crust) layer and bottom layer. Balady bread dough is softer (70-75\% water) compared to other bread types and has lower protein content. Soft dough is fermented to $2 \mathrm{~h}$ then baked at high temperature (400-500 ${ }^{\circ} \mathrm{C}$ ) for 1-2 min. During baking gasses expansion takes place resulting in tow layers and thus called oven spring. Balady bread has higher surface area and higher crust/ crumb ratio due to it has very small crumb layer (Yaseen et al., 2007).

The present study was carried out to develop sustainable methods such as solid-state fermentation and superfine grinding (nano- size) as well as the combination between them in order to modify the structure of tested food by-products (wheat bran, wheat germ, rice bran, carrot pomace and pomegranate peel). Moreover, wheat flour was substituted using the obtained nano and fermented nano-food by-products.

\section{Materials and Methods}

\section{Materials}

Wheat flour (72\%), Wheat flour (82\%), whole-meal wheat, wheat bran and wheat germ were obtained from North Cairo Flour Mills Company, Egypt. Rice bran was obtained from Rice Research and Training Centre, Sakha, Kafr El-Sheikh, Egypt. Carrot (Daucus carota) and pomegranate fruits (Punica granatum L.) were purchased from the local market, Giza, Egypt. Active dry yeast (Saccharomyces cerevisiae) was obtained from Egyptian Sugar and Integrated Industries Company (ESIIC), Chemicals Factory, El-Hawamdia City, Giza, Egypt.

\section{Methods}

\section{Stabilization of wheat germ and rice bran}

Wheat germ and rice bran were stabilized in a hot air-oven at a temperature of $120 \pm 2{ }^{\circ} \mathrm{C}$ for 1 min according to Younas et al. (2011). The stabilized wheat germ and rice bran were ground using Moulinex grinder (Moulinex 753, Mexico) to pass through a $40-\mathrm{mesh}(420 \mu \mathrm{m})$ and packed in polyethylene bags and stored at $-30{ }^{\circ} \mathrm{C}$ until use.

\section{Preparation of carrot pomace}

Carrot pomace was obtained after juice extraction (Juice extractor, Moulinex 753, Mexico). Carrot pomace was dried in an air-oven at $50 \pm 1^{\circ} \mathrm{C}$ for $16 \mathrm{~h}$. The dried sample was ground using Moulinex grinder and passed through a 40mesh sieve and packed in polyethylene bags and stored at $-30{ }^{\circ} \mathrm{C}$ until use.

\section{Preparation of Pomegranate peel}

The peel of Pomegranate was manually removed and dried in an air-oven at $50 \pm 1{ }^{\circ} \mathrm{C}$ for $16 \mathrm{~h}$. The dried sample was ground using Moulinex grinder and passed through a 40-mesh sieve and packed in polyethylene bags and stored at $-30^{\circ} \mathrm{C}$ until use.

\section{Solid-state yeast fermentation}

Yeast strain (Saccharomyces cerevisiae FC620) was obtained from Microbial Chemistry Dept. Collection, National Research Centre, Dokki, Cairo, Egypt. The yeast cells were activated, a loopful of the culture was transferred to $250 \mathrm{~mL}$ Erlenmeyer flask containing $50 \mathrm{~mL}$ broth medium $(0.3 \%$ yeast extract, $0.3 \%$ malt extract, $0.5 \%$

Egypt. J. Food. 47, No. 2 (2019) 
peptone and 5\% sucrose) and incubated for $24 \mathrm{hr}$ at $32^{\circ} \mathrm{C}$ under shaking condition. Solid-state yeast treatment was carried out according to the method of Moore et al. (2007) as follows: $50 \mathrm{~mL}$ of yeast preparation $(1380 \mathrm{cfu} / \mathrm{mL})$ was mixed with $100 \mathrm{~g}$ sample in a sterile conical flask. Flasks were sealed with cotton seals and incubated at $32^{\circ} \mathrm{C}$ for 48h. All treated samples were dried at $50 \pm 1{ }^{\circ} \mathrm{C}$ for $16 \mathrm{~h}$ and stored in polyethylene bags at $-30^{\circ} \mathrm{C}$ until use.

Preparation of nano and fermented-nano materials

The raw wheat bran and wheat germ and fermented rice bran, carrot pomace and pomegranate peels were ground using $5 \mathrm{~mm}$ zirconium oxide ball and zirconium oxide bowl volume $250 \mathrm{~mL}$ in a PM 100 Planetary Ball-mill (Retsch, Germany) as described by Zhu et al.
(2010) with some modifications. Samples (150g) were ground at $30 \mathrm{~Hz}$ frequency for $60 \mathrm{~min}$ at room temperature.

Transmission Electron Microscopy (TEM)

All ground samples were examined with a JEOL JX 1230 technique with micro analyzer probe, Japan. This technique was used to determine the particle size of the investigated samples according to Casuccio et al. (2004).

\section{Preparation of functional formulas}

Nano- wheat bran, nano-wheat germ, fermented-nano rice bran, fermented-nano carrot pomace and fermented-nano pomegranate peel were used to replace wheat flour ( $72 \%$ extraction) at 5,15 and $25 \%$ levels. Control samples were made from wheat flour $72 \%$ extraction, $82 \%$ extraction and whole-meal flourfor comparison as shown in Table 1.

TABLE 1. Preparation of Egyptian balady bread formulas (g/100 g).

\begin{tabular}{|c|c|c|c|c|c|c|c|c|}
\hline \multirow{2}{*}{$\begin{array}{c}\text { *Formula } \\
\text { No. }\end{array}$} & \multicolumn{3}{|c|}{ Wheat flour extraction (\%) } & \multirow{2}{*}{ NWB } & \multirow{2}{*}{ NWG } & \multirow{2}{*}{ FNRB } & \multirow{2}{*}{ FNCP } & \multirow{2}{*}{ FNPP } \\
\hline & 72 & 82 & 100 & & & & & \\
\hline 1 & 100 & --- & --- & --- & --- & --- & --- & --- \\
\hline 2 & --- & 100 & --- & --- & --- & --- & --- & --- \\
\hline 4 & 95 & --- & --- & 5 & --- & --- & --- & --- \\
\hline 5 & 85 & --- & --- & 15 & --- & --- & --- & --- \\
\hline 6 & 75 & --- & --- & 25 & --- & --- & --- & --- \\
\hline 9 & 75 & --- & --- & --- & 25 & --- & --- & --- \\
\hline 10 & 95 & --- & --- & --- & --- & 5 & --- & --- \\
\hline 11 & 85 & --- & --- & --- & --- & 15 & --- & --- \\
\hline 12 & 75 & --- & --- & --- & --- & 25 & --- & --- \\
\hline 13 & 95 & --- & --- & --- & --- & --- & 5 & --- \\
\hline 14 & 85 & --- & --- & --- & --- & --- & 15 & --- \\
\hline
\end{tabular}

* Baker's yeast (1\%), sodium chloride $(1.5 \%)$ and required water were added to each formula

$\mathrm{NWB}=$ nano-wheat bran, NWG $=$ nano-wheat germ, FNCP $=$ fermented-nano-carrot pomace, FNPP $=$ fermented-nano- pomegranate peel. 
Processing of Egyptian balady bread

According to Yaseen et al. (2007) balady bread was prepared by mixing wheat flour $(72 \%$ extraction), prepared food by-products, baker's yeast $(1 \%)$, sodium chloride $(1.5 \%)$ and water for about $6 \mathrm{~min}$ to form the needed dough. The dough was left to ferment for $1 \mathrm{~h}$ at $30^{\circ} \mathrm{C}$ temperature and $85 \%$ relative humidity, and then divided into $150 \mathrm{~g}$ pieces. The pieces were arranged on a wooden board that had been sprinkled with a fine layer of bran and left to ferment for about $45 \mathrm{~min}$ at the same temperature and relative humidity. The pieces of fermented dough were flattened to about $20 \mathrm{~cm}$ in diameter. The flattened loaves were proofed at $30-35^{\circ} \mathrm{C}$ and $85 \%$ relative humidity for $15 \mathrm{~min}$ and then baked at $400-500^{\circ} \mathrm{C}$ for $1-2 \mathrm{~min}$. The loaves of bread were allowed to cool on racks for about $1 \mathrm{hr}$.

\section{Color measurements}

The color of balady bread was measured using a spectrocolorimeter with the CIE color scale (Hunter, Lab scan XE) (Commission International de l'Eclairage (CIE), 1976). This instrument was standardized against the white tile of Hunter Lab color standard (LX No.16379): $\mathrm{X}=77.26, \mathrm{Y}=$ 81.94 and $\mathrm{Z}=88.14$. The $\mathrm{L}^{*}, \mathrm{a}^{*}$ and $\mathrm{b}^{*}$ values were reported. Total color difference $(\Delta \mathrm{E})$ was calculated as :

$$
\begin{aligned}
& \Delta \Delta \mathrm{E}=\left[\left(\Delta \mathrm{L}^{*}\right)^{2}+(\Delta \mathrm{a} *)^{2}+\left(\Delta \mathrm{b}^{*}\right)^{2}\right]^{0.5} \\
& \text { Organoleptic evaluation of Egyptian balady } \\
& \text { bread }
\end{aligned}
$$

Organoleptic evaluation of balady bread loaves was conducted for the freshly baked breads by 10 semi-trained panelists from the staff (male and female) aged from 25 to 60 years old from Food Industries and Nutrition Division, National Research Centre, Egypt according to El-Farra et al. (1982). The tested characteristics were general appearance (20), separation of layers (20), roundness (15), distribution of crumb (15), crust color (10), taste (10) and odor (10).

\section{Freshness of Egyptian balady bread}

Loaves freshness of each packed sample was tested at room temperature $\left(25^{\circ} \mathrm{C}\right)$ during storage for 24,48 and $72 \mathrm{hr}$ by alkaline water retention capacity (AWRC) according to method of Yamazaki (1953), as modified by Kitterman and Rubenthaler (1971). Five grams $\left(W_{1}\right)$ of bread flour was placed into $50 \mathrm{~mL}$ dry weighed plastic centrifuge tube $\left(\mathrm{W}_{2}\right) .25 \mathrm{~mL}$ sodium hydrogen carbonate $\left(\mathrm{NaHCO}_{3}\right)$ solution $(8.4 \mathrm{~g} / \mathrm{L})$ was added. The tube was closed and shaken using vortex shaker to disperse its content, then the mixture was left for $20 \mathrm{~min}$. The contents were then centrifuged at $2500 \mathrm{rpm}$ for $15 \mathrm{~min}$. The supernatant was decanted and the precipitate left for $10 \mathrm{~min}$ at 45 angles (to get rid of free water) and weighed. The gain in weight was calculated as follow:

$\frac{\left(\mathrm{W}_{3}\right)-\left(\mathrm{W}_{1}+\mathrm{W}_{2}\right)}{\mathrm{W}_{1}} \times 100$

Loss of freshness (\%) was calculated using the following equation:

$\frac{\left(\mathrm{AWRC}_{\text {zero time }}\right)-\left(\mathrm{AWRC}_{\mathrm{n} \text { time }}\right)}{\mathrm{AWRC}_{\text {zero time }}} \times 100$

Where $n=$ time of storage

\section{Statistical analysis}

All samples were analyzed in triplicates and the mean values were expressed. Analysis was assessed using the Statistical Analysis Software for Windows (SAS, 2008). The significant difference between the mean values were determined by using the analysis of variance (ANOVA) and Duncan's multiple range test was conducted at a significance level of $\mathrm{p}<0.05$.

\section{Results and Discussion}

Transmission Electron Microscopy (TEM)

The TEM images showed that the particle size of $\mathrm{WB}, \mathrm{WG}, \mathrm{RB}, \mathrm{CP}$ and $\mathrm{PP}$ was distributed in a range of $10-21,7-19,15-47,8-58$ and $21-$ $35 \mathrm{~nm}$, respectively, which indicated that they are in the nano-scale. The details of these data were previously published in Mohammad et al. (2015).

Organoleptic characteristics of balady bread

Data in Table 2 present the organoleptic characteristics (general appearance, layers separation, roundness, crumb distribution, crust color, taste and odor) of the control and nano and fermented-nano enriched bread samples conducted with 10 panelists. The panelists gave control sample (bread made from wheat flour $72 \%$ extraction) the highest scores for all organoleptic characteristics. On contrary, balady bread samples incorporated with FNCP and FNPP at 15 and $25 \%$ were scored below acceptability rang. There were no significant differences between the bread samples made from wheat flour $82 \%$, wheat flour $100 \%$, wheat flour incorporated NWB up to $25 \%$, NWG up to $5 \%$ and control sample for all measured characteristics. Panelist 
scores for general appearance were markedly declined with increasing supplementation levels of NWG more than $15 \%$, FNRB more than $5 \%$, as well as FNCP and FNPP at all supplementation levels. The scores of layers separation, roundness and crumb distribution showed the same trend. The increase in fiber contents of bread leads to weakening of gluten network, so its ability to retain the gasses that formed and expanded during oven spring decreased (Schleibinger et al., 2013). Consequently, the layers separation and crumb distribution of these samples were significantly affected. These results are in accordance with those obtained by Seleem and Omran (2014) and Eshak (2016).

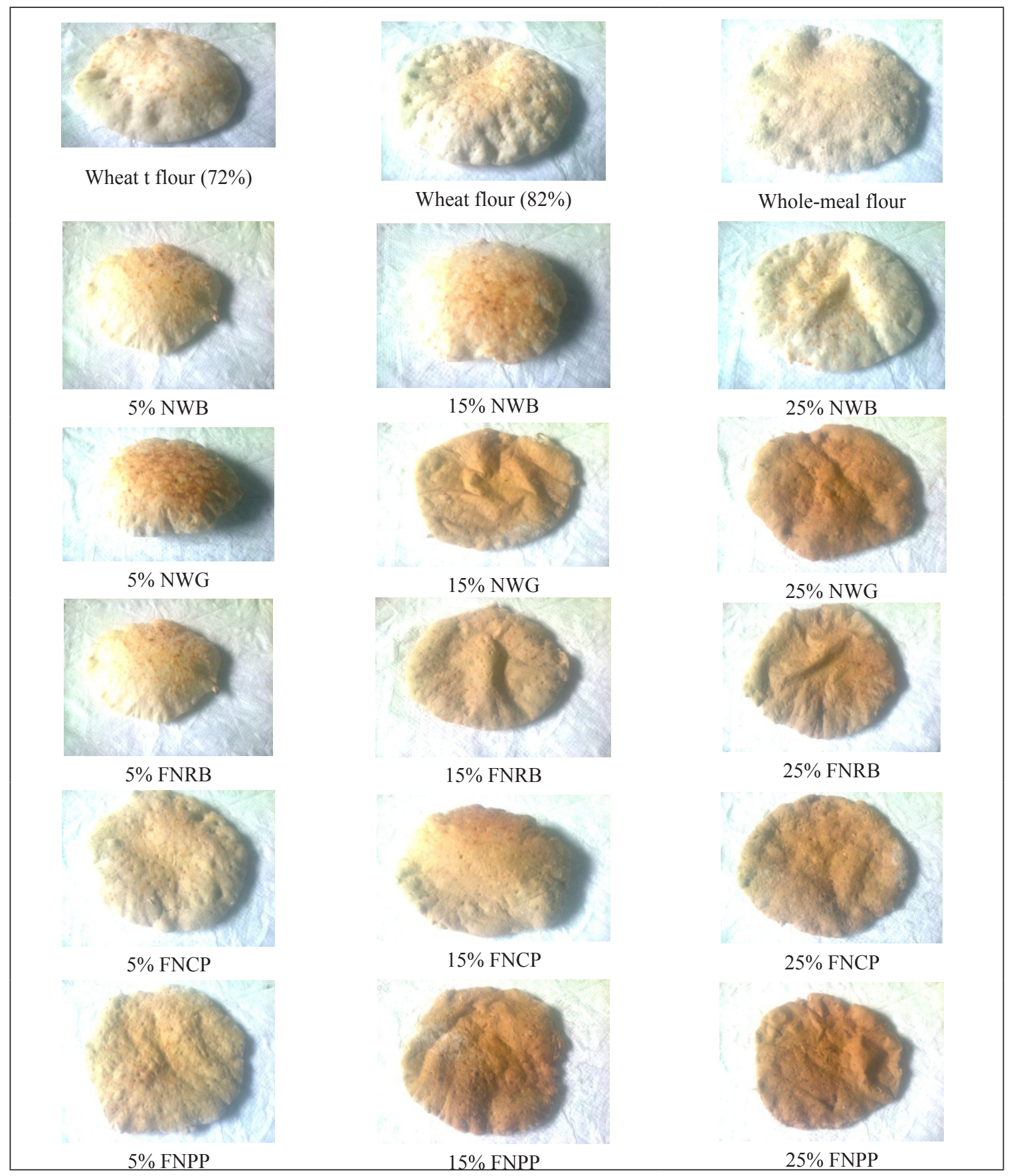

Fig. 1. Photographs of balady bread as affected by addition of nano and fermented-nano materials compared with control samples.

$\mathrm{NWB}=$ wheat bran; $\mathrm{NWG}=$ nano wheat germ; FNRB $=$ fermented-nano rice bran; FNCP = fermented-nano carrot pomace; FNPP = fermented-nano pomegranate peel. 


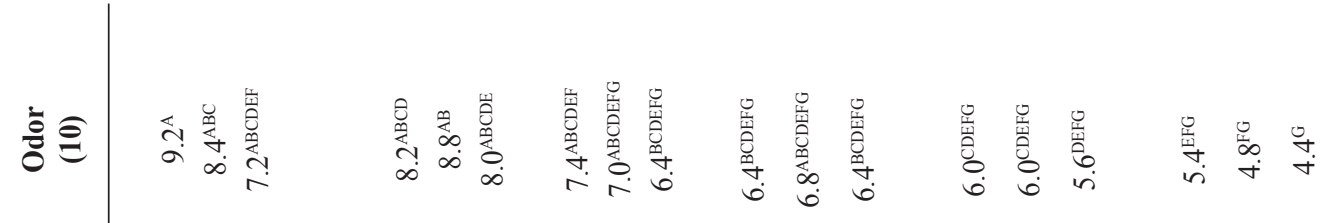

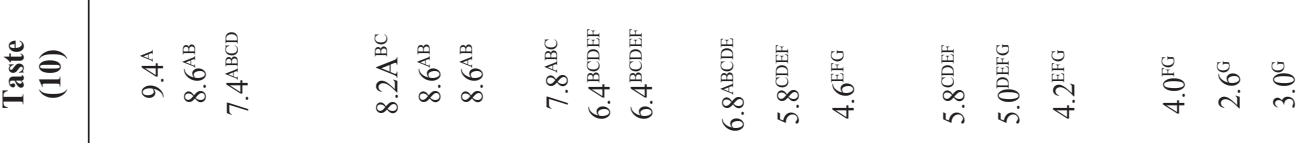

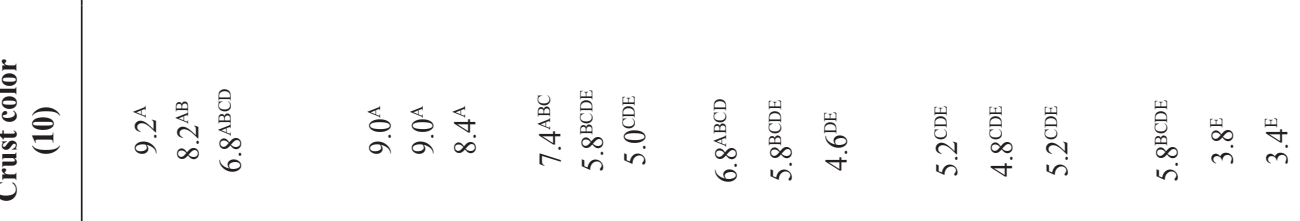

离

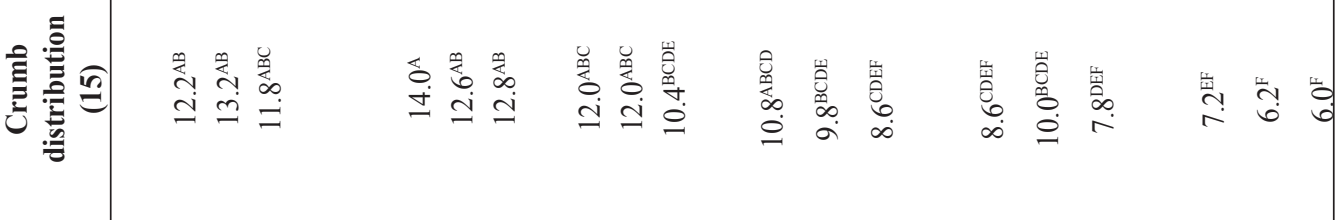

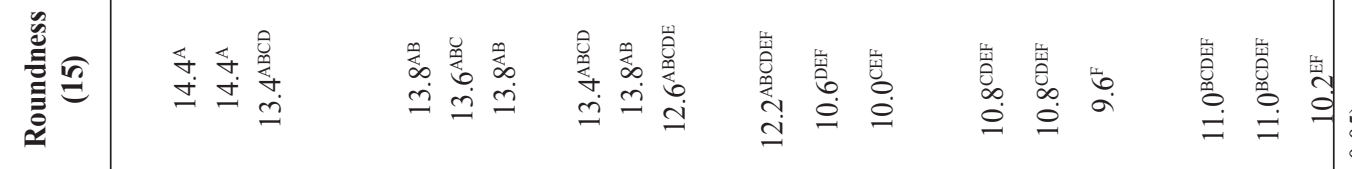

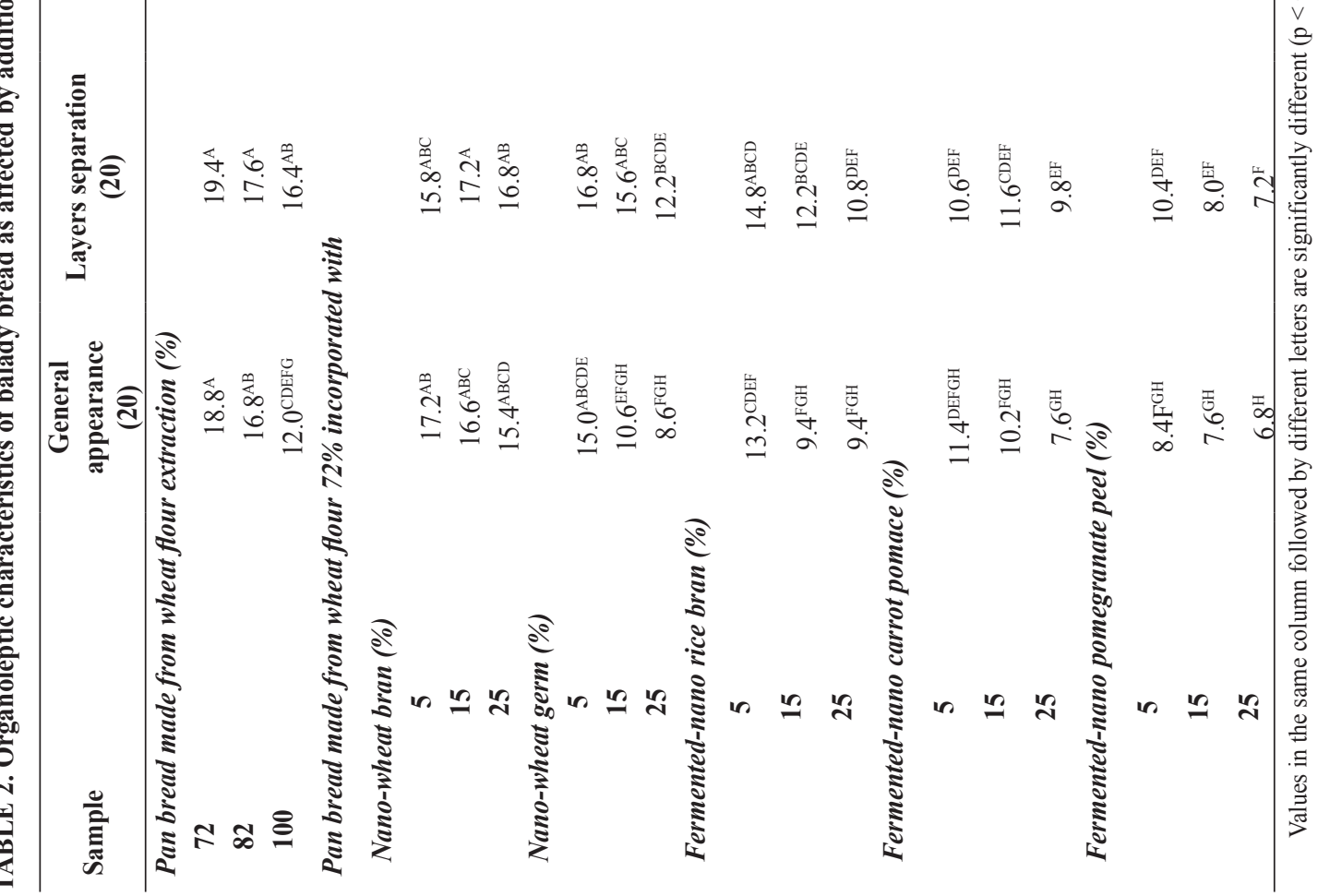

Egypt. J. Food. 47, No. 2 (2019) 
It was observed that increasing the level of FNRB, FNCP and FNPP increased the darkness of the prepared bread (Fig. 1). Crust color scores of these samples ranged from 3.4 to 7.4 compared to 9.2 for the bread made from $72 \%$ wheat flour. Also, the mean scores of balady bread odor were significantly decreased in these samples as compared to control. Same trend was observed in taste, which showed that addition of NWG or FNRB more than $15 \%$ and FNCP or FNPP more than $5 \%$ negatively affected the final product in terms of taste and odor (Table 2). Regarding the measured characteristics, the panelists refused breads incorporated 25\% FNCP, as well as 15 and $25 \%$ FNPP.

Regarding organoleptic evaluation data, mean scores of aroma (taste and flavor) and texture of bread were decreased as the industrial by-products levels increased (Bhol et al., 2016; Belghith et al., 2016b; Stoll et al., 2015 and Wu and Shiau, 2015). However, this effect was not observed in some formulations of wheat bread fortified with some industrial by-products such as brewers spent grain and grape seeds. Moreover, other industrial byproducts such as pomegranate bagasses, brewers spent yeast, pumpkin seeds cake and tomato pomace improved the mean scores of some bread characteristics (Majzoobi et al., 2011; Pathak et al., 2016 and Martins et al., 2015).

Color attributes of control and functional balady bread

The color characteristics $\left(\mathrm{L}^{*}, \mathrm{a}^{*}, \mathrm{~b}^{*}\right.$ and $\left.\Delta \mathrm{E}\right)$ of both top and bottom layers of balady bread are given in Tables 3 and 4. Data showed that there were no significant differences $(p<0.05)$ between the top layer lightness ( $\mathrm{L}^{*}$ value) of bread samples partially substituted with NWB up to $15 \%$ and those made from wheat flour 72 and $82 \%$ extraction. Also, there were no significant differences between $L^{*}$ values of the top layer of bread incorporated $25 \%$ NWB, 5 and $15 \%$ FNRB, 5\% NWG, FNCP, FNPP and the crust of whole-meal bread. While, the top layer of bread incorporated NWG, FNCP and FNPP at the levels of 15 and $25 \%$ showed significantly lower $\mathrm{L}^{*}$ values.

TABLE 3. Color attributes of the top layer of balady bread as affected by addition of nano and fermented-nano materials.

\begin{tabular}{|c|c|c|c|c|}
\hline Sample & $\begin{array}{c}\text { Lightness } \\
\left(L^{*}\right)\end{array}$ & $\begin{array}{c}\text { Redness } \\
\left(a^{*}\right)\end{array}$ & $\begin{array}{c}\begin{array}{c}\text { Yellowness } \\
\left(\mathbf{b}^{*}\right)\end{array} \\
\end{array}$ & $\begin{array}{c}\text { Total color } \\
\text { differences }(\Delta \mathrm{E})\end{array}$ \\
\hline \multicolumn{5}{|c|}{ Balady bread made from wheat flour extraction (\%) } \\
\hline 72 & $75.34^{\mathrm{A}}$ & $2.52^{\mathrm{I}}$ & $21.73^{\mathrm{H}}$ & 0.0 \\
\hline 82 & $68.19^{\mathrm{AB}}$ & $3.84^{\mathrm{HI}}$ & $22.19^{\mathrm{GH}}$ & $6.7^{3 \mathrm{IJK}}$ \\
\hline 100 & $59.96^{\mathrm{BCD}}$ & $9.20^{\mathrm{BCDEF}}$ & $21.62^{\mathrm{H}}$ & $16.21^{\mathrm{FGHI}}$ \\
\hline \multicolumn{5}{|c|}{ Balady bread made from wheat flour $72 \%$ incorporated with } \\
\hline \multicolumn{5}{|c|}{ Nano-wheat bran (\%) } \\
\hline 5 & $69.58^{\mathrm{AB}}$ & $2.97^{\mathrm{I}}$ & $19.95^{\mathrm{I}}$ & $5.31^{\mathrm{JK}}$ \\
\hline 15 & $67.18^{\mathrm{AB}}$ & $3.84^{\mathrm{HI}}$ & $24.43^{\mathrm{DEF}}$ & $8.29^{\mathrm{HIJK}}$ \\
\hline 25 & $63.00^{\mathrm{BC}}$ & $4.64^{\mathrm{GHI}}$ & $25.99^{\mathrm{BC}}$ & $12.81^{\mathrm{GHIJ}}$ \\
\hline \multicolumn{5}{|c|}{ Nano-wheat germ (\%) } \\
\hline 5 & $60.69^{\mathrm{BC}}$ & $8.88^{\mathrm{CDEF}}$ & $26.98^{\mathrm{AB}}$ & $16.44^{\mathrm{FGHI}}$ \\
\hline 15 & $47.78^{\mathrm{EFGH}}$ & $11.89^{\mathrm{AB}}$ & $27.22^{\mathrm{AB}}$ & $29.14^{\mathrm{ABCD}}$ \\
\hline 25 & $40.47^{\mathrm{H}}$ & $13.29^{\mathrm{A}}$ & $24.86^{\mathrm{CDE}}$ & $36.08^{\mathrm{A}}$ \\
\hline \multicolumn{5}{|c|}{ Fermented-nano rice bran (\%) } \\
\hline 5 & $60.48^{\mathrm{BC}}$ & $6.65^{\mathrm{FGH}}$ & $24.03^{\mathrm{DEF}}$ & $15.10^{\text {FGHIJ }}$ \\
\hline 15 & $55.89^{\mathrm{CDE}}$ & $7.00^{\mathrm{EFG}}$ & $22.11^{\mathrm{H}}$ & $19.36^{\mathrm{DEFG}}$ \\
\hline 25 & $50.54^{\mathrm{DEFG}}$ & $7.98^{\mathrm{DEF}}$ & $23.61^{\mathrm{EFG}}$ & $24.90^{\mathrm{BCDEF}}$ \\
\hline \multicolumn{5}{|c|}{ Fermented-nano carrot pomace (\%) } \\
\hline 5 & $56.86^{\mathrm{CDE}}$ & $6.40^{\mathrm{FGH}}$ & $23.00^{\mathrm{FGH}}$ & $18.36^{\mathrm{EFGH}}$ \\
\hline 15 & $49.35^{\mathrm{EFGH}}$ & $10.62^{\mathrm{ABCD}}$ & $26.29^{\mathrm{ABC}}$ & $27.10^{\mathrm{ABCDE}}$ \\
\hline 25 & $44.83^{\mathrm{FGH}}$ & $9.94^{\mathrm{BCDE}}$ & $25.17^{\mathrm{CD}}$ & $31.10^{\mathrm{ABC}}$ \\
\hline \multicolumn{5}{|c|}{ Fermented-nano pomegranate peel (\%) } \\
\hline 5 & $53.75^{\mathrm{CDEF}}$ & $7.63^{\mathrm{EF}}$ & $26.99 \mathrm{~A}^{\mathrm{B}}$ & $22.32^{\mathrm{CDEFG}}$ \\
\hline 15 & $47.28^{\mathrm{EFGH}}$ & $9.12^{\mathrm{BCDEF}}$ & $27.66^{\mathrm{A}}$ & $28.93^{\mathrm{ABCD}}$ \\
\hline 25 & $42.90^{\mathrm{GH}}$ & $10.94^{\mathrm{ABC}}$ & $27.24^{\mathrm{AB}}$ & $33.45^{\mathrm{AB}}$ \\
\hline
\end{tabular}


TABLE 4. Color attributes of the bottom layer of balady bread as affected by addition of nano and fermented-nano materials.

\begin{tabular}{ccccc}
\hline \multicolumn{1}{c}{ Sample } & $\begin{array}{c}\text { Lightness } \\
\left(\mathbf{L}^{*}\right)\end{array}$ & $\begin{array}{c}\text { Redness } \\
\left(\mathbf{a}^{*}\right)\end{array}$ & $\begin{array}{c}\text { Yellowness } \\
\left(\mathbf{b}^{*}\right)\end{array}$ & $\begin{array}{c}\text { Total color } \\
\text { differences }(\boldsymbol{\Delta E})\end{array}$ \\
\hline Balady bread made from wheat flour extraction $(\%)$ & & & \\
$\mathbf{7 2}$ & $72.21^{\mathrm{A}}$ & $4.60^{\mathrm{GH}}$ & $22.92^{\mathrm{B}}$ & 0.0 \\
$\mathbf{8 2}$ & $66.37^{\mathrm{B}}$ & $5.51^{\mathrm{EFG}}$ & $22.12^{\mathrm{B}}$ & $5.48^{\mathrm{H}}$ \\
$\mathbf{1 0 0}$ & $59.39^{\mathrm{CD}}$ & $7.08^{\mathrm{BCDE}}$ & $22.32^{\mathrm{B}}$ & $12.44^{\mathrm{DEFG}}$
\end{tabular}

Balady bread made from wheat flour $72 \%$ incorporated with

Nano-wheat bran (\%)

$\begin{array}{lcccc}\mathbf{5} & 69.26^{\mathrm{AB}} & 3.66^{\mathrm{H}} & 19.09^{\mathrm{EF}} & 5.41^{\mathrm{H}} \\ \mathbf{1 5} & 67.07^{\mathrm{B}} & 5.50^{\mathrm{EFG}} & 22.17^{\mathrm{B}} & 4.82^{\mathrm{H}} \\ \mathbf{2 5} & 60.05^{\mathrm{CD}} & 6.97^{\mathrm{BCDE}} & 24.95^{\mathrm{A}} & 11.72^{\mathrm{FG}}\end{array}$

Nano-wheat germ (\%)

\begin{tabular}{|c|c|c|c|c|}
\hline 5 & $56.80^{\mathrm{DE}}$ & $6.26^{\mathrm{CDEF}}$ & $19.79^{\mathrm{DE}}$ & $15.33^{\mathrm{CDE}}$ \\
\hline 15 & $54.83^{\mathrm{E}}$ & $8.42^{\mathrm{AB}}$ & $22.83^{\mathrm{B}}$ & $17.10^{\mathrm{C}}$ \\
\hline 25 & $45.66^{\mathrm{G}}$ & $8.79^{\mathrm{A}}$ & $21.29^{\mathrm{BCD}}$ & $26.29^{\mathrm{A}}$ \\
\hline \multicolumn{5}{|c|}{ rmented-nano rice bran (\%) } \\
\hline 5 & $62.34^{\mathrm{C}}$ & $4.71^{\mathrm{FGH}}$ & $19.46^{\mathrm{E}}$ & $10.17^{\mathrm{G}}$ \\
\hline 15 & $56.29^{\mathrm{DE}}$ & $6.74^{\mathrm{CDE}}$ & $21.74^{\mathrm{BC}}$ & $15.49^{\mathrm{CD}}$ \\
\hline 25 & $56.31^{\mathrm{DE}}$ & $6.22^{\mathrm{CDEF}}$ & $17.79^{\mathrm{F}}$ & $16.50^{\mathrm{C}}$ \\
\hline \multicolumn{5}{|c|}{ mented-nano carrot pomace (\%) } \\
\hline 5 & $59.87^{\mathrm{CD}}$ & $5.96^{\mathrm{DEFG}}$ & $21.75^{\mathrm{BC}}$ & $11.89^{\mathrm{EFG}}$ \\
\hline 15 & $56.76^{\mathrm{DE}}$ & $7.62^{\mathrm{ABC}}$ & $21.89^{\mathrm{BC}}$ & $15.14^{\mathrm{CDEFG}}$ \\
\hline 25 & $50.42^{\mathrm{F}}$ & $7.40^{\mathrm{ABCD}}$ & $20.40^{\mathrm{CDE}}$ & $21.53^{\mathrm{B}}$ \\
\hline \multicolumn{5}{|c|}{ mented-nano pomegranate peel (\%) } \\
\hline 5 & $57.90^{\mathrm{DE}}$ & $5.91^{\mathrm{DEFG}}$ & $20.08^{\mathrm{DE}}$ & $14.25^{\mathrm{CDEF}}$ \\
\hline 15 & $46.98^{\mathrm{G}}$ & $6.98^{\mathrm{BCDE}}$ & $20.48^{\mathrm{CDE}}$ & $24.86^{\mathrm{A}}$ \\
\hline 25 & $45.29^{\mathrm{G}}$ & $7.65^{\mathrm{ABC}}$ & $20.10^{\mathrm{DE}}$ & $26.64^{\mathrm{A}}$ \\
\hline
\end{tabular}

Values in the same column followed by different letters are significantly different $(p<0.05)$

As can be seen in Table 3, the lowest L* value (40.47) was recorded to the top layer of bread containing $25 \%$ NWG compared to 75.34 and 59.96 for the top layer of bread made from wheat flour 72 and $100 \%$, respectively. The darkness of bread containing NWG could be due to Millard reaction, while the darkness of bread containing FNCP and FNPP could be due to the dark color of the added powder itself. The same trend was also noticed when $\mathrm{L}^{*}$ values of the bottom layer were considered.
Redness $\left(a^{*}\right)$ values of the top and bottom layers of balady bread showed opposite trend to $\mathrm{L}^{*}$ values. Bread samples incorporated 15 and $25 \%$ NWG, FNCP and FNPP had significantly higher $\mathrm{a}^{*}$ values compared to other samples Tables (2 and 3). There were no significant differences between $a^{*}$ values of the top layer of bread made from wheat flour 72 and $82 \%$ and those containing NWB at all levels being 2.52, 3.84, 2.97, 3.84 and 4.64, respectively. As mentioned above, the brown color of top layer is 
known to be the result of Maillard reaction, thus high protein content could promote the occurrence of Maillard reaction (Gomez et al., 2003). So, addition of NWG significantly increased $a^{*}$ value. The highest $\mathrm{a}^{*}$ value was recorded to bread incorporated $25 \%$ NWG being 13.29 and 8.79 for the top and bottom layers, respectively. The high $a^{*}$ values of bread containing NWG could be to its high protein content.

Yellowness $\left(b^{*}\right)$ value of both top and bottom layers of balady bread were significantly different and showed different trends. The top layer of bread samples containing NWG, FNCP and FNPP showed higher $b^{*}$ values compared to other samples Tables (3 and 4). While, $b^{*}$ values of the bottom layer of bread made from wheat flour $72,82,100 \%$ and wheat flour incorporated NWB up to $25 \%$ were significantly higher compared to other samples. The higher $b^{*}$ values of top layers of balady bread samples compared to the bottom layers could be due to the baking method, where the top layer directly faces the oven fire. The top layer of bread sample incorporated 15\% FNPP showed the highest $b^{*}$ being 27.66 , while the lowest $b^{*}$ value was recorded to the top layer of bread incorporated 5\% NWB, 19.95. But the bottom layer of bread incorporated 25\% NWB showed the highest $b^{*}$ value, 24.95, while the lowest value was recorded to the bottom layer of bread containing $25 \%$ FNRB being 17.79 .

Regarding total color differences $(\Delta \mathrm{E})$, the top layer color of bread samples made from wheat flour $82 \%$ and those containing NWB up to $15 \%$ was more homogenous compared to control sample. On contrary, the top layer color of bread samples containing NWG, FNCP and FNPP showed asymmetry color properties (Table 2). Generally, it could be concluded that NWB up to $25 \%$ was more suitable to produce high fiber balady bread with low $\Delta \mathrm{E}$ value compared to bread made from wheat flour $72 \%$. The lowest $\Delta \mathrm{E}$ value was recorded to the top layer of the sample containing 5\% NWB, 5.31, while the highest value was recorded to the sample containing $25 \%$ NWG being 36.08. The same trend was observed when $\Delta \mathrm{E}$ values of the bottom layer of bread were considered.

Decreased lightness ( $\mathrm{L}^{*}$ value) in bread fortified with potential functional ingredients from industrial by-products was frequently noticed (Belghith et al., 2016a; Shiau et al., 2015; Martins et al., 2015 and Martins et al., 2017). Maillard and caramelization reactions are usually the major reasons of the darker color quality of processed food products, but the native color of utilized byproducts also influenced the color quality of the final products (Juszczak et al., 2012; Peressini and Sensidoni, 2009 and Martins et al., 2017).

Freshness properties of balady bread as affected by addition of nano and fermented-nanomaterials

Results in Table 5 showed that there was a gradual decrease in swelling power of all balady bread samples after baking. The control bread showed significantly higher AWRC values at zero time (306.11\%) and during 24 (254.18\%) and $48 \mathrm{~h}(194.84 \%)$, but after $72 \mathrm{~h}$ bread sample containing 5\% FNRB showed the highest AWRC value being $159.96 \%$ compared to $150.33 \%$ for the control sample. While, balady bread made from whole-meal flour showed the lowest AWRC values during storage time $(140.19,106.72$ and $81.62 \%$ at 24,48 and $72 \mathrm{hr}$, respectively). Also, data presented in this table showed significant negative effects of adding fiber materials on the swelling power of balady bread samples at zero time compared to control sample. The highest negative effect was recorded for FNPP at the level of $25 \%(160.94 \%)$.

Figure 2 shows that addition of nano and fermented-nano materials retarded the staling of balady bread samples during storage period ( $72 \mathrm{hr}$ ) at room temperature. Balady bread manufactured using wheat flour $72 \%$ and whole-meal flour had faster staling rate. They loosed their freshness at the rate of 16.96 and $17.28 \%, 36.35$ and $37.03 \%$ and 50.89 and $51.83 \%$ after 24,48 and $72 \mathrm{hr}$, respectively. While, balady bread containing $25 \%$ FNCP had the lowest staling rate as it loosed only $8.63,18.49$ and $25.89 \%$ from its original freshness after 24, 48 and $72 \mathrm{hr}$, respectively. Also, bread samples containing 25\% NWG, 15\% FNRB and $15 \%$ FNPP had low staling rate. For instance, these samples lost 35.12, 34.05 and $31.37 \%$ from their original freshness after $72 \mathrm{hr}$, respectively.

Also, a reversed relationship between the staling rate and the level of addition was observed in all tested materials except FNRB. Addition Egypt. J. Food. 47, No. 2 (2019) 
of FNRB at $25 \%$ increased the staling rate of produced bread being $41.8 \%$ after $72 \mathrm{hr}$ of storage compared to $34.05 \%$ for bread containing $15 \%$ FNRB after the same time. The obtained results are in accordance with the results of Feili et al. (2013) who attributed this effect to the fiber capability of water binding and the potential interaction between fiber and starch. Under these conditions, water loss and starch retrogradation during storage are delayed.

\section{Conclusion}

From the obtained results it could be concluded that, functional Egyptian balady bread with acceptable quality could be prepared using wheat flour replaced by NWB or NWG up to $25 \%$ or FNRP up to $15 \%$, FNCP or FNPP up to $5 \%$.

\section{Acknowledgement}

The authors gratefully acknowledge the National Research Center, Egypt fund (Project No.10090002) for their financial support of this work.

TABLE 5. Alkaline water retention capacity of balady bread as affected by addition of nano and fermented-nano materials (\%).

\begin{tabular}{|c|c|c|c|c|}
\hline \multirow{2}{*}{ Sample } & \multicolumn{4}{|c|}{ Storage time (h) } \\
\hline & Zero & 24 & 48 & 72 \\
\hline \multicolumn{5}{|c|}{ Balady bread made from wheat flour extraction (\%) } \\
\hline 72 & $306.11^{\mathrm{A}}$ & $254.18^{\mathrm{A}}$ & $194.84^{\mathrm{A}}$ & $150.33^{\mathrm{B}}$ \\
\hline 82 & $237.90^{\mathrm{E}}$ & $201.06^{\mathrm{F}}$ & $158.94^{\mathrm{G}}$ & $127.36^{\mathrm{HI}}$ \\
\hline 100 & $169.47^{\mathrm{N}}$ & $140.19^{\mathrm{L}}$ & $106.72^{\mathrm{M}}$ & $81.62^{\mathrm{L}}$ \\
\hline \multicolumn{5}{|c|}{ Balady bread made from wheat flour $82 \%$ incorporated with } \\
\hline \multicolumn{5}{|c|}{ Nano-wheat bran (\%) } \\
\hline 5 & $260.08^{\mathrm{B}}$ & $219.59^{C}$ & $173.31^{\mathrm{D}}$ & $138.61^{\mathrm{CD}}$ \\
\hline 15 & $234.51^{\mathrm{F}}$ & $205.47^{\mathrm{E}}$ & $172.28^{\mathrm{D}}$ & $147.39^{\mathrm{B}}$ \\
\hline 25 & $200.26^{\mathrm{KL}}$ & $176.17^{\mathrm{J}}$ & $148.64^{\mathrm{J}}$ & $127.99^{\mathrm{GHI}}$ \\
\hline \multicolumn{5}{|c|}{ Nano-wheat germ (\%) } \\
\hline 5 & $226.72^{\mathrm{H}}$ & $193.16^{\mathrm{HI}}$ & $154.81^{\mathrm{H}}$ & $126.05^{1}$ \\
\hline 15 & $243.43^{\mathrm{D}}$ & $212.46^{\mathrm{D}}$ & $177.06^{\mathrm{C}}$ & $150.51^{\mathrm{B}}$ \\
\hline 25 & $202.20^{\mathrm{K}}$ & $178.53^{\mathrm{J}}$ & $151.48^{\mathrm{I}}$ & $131.19^{\mathrm{FG}}$ \\
\hline \multicolumn{5}{|c|}{ Fermented-nano rice bran (\%) } \\
\hline 5 & $253.73^{\mathrm{C}}$ & $222.47^{\mathrm{B}}$ & $186.75^{\text {B }}$ & $159.96^{\mathrm{A}}$ \\
\hline 15 & $227.57^{\mathrm{H}}$ & $201.75^{\mathrm{F}}$ & $172.23^{\mathrm{D}}$ & $150.09^{\mathrm{B}}$ \\
\hline 25 & $230.58^{\mathrm{G}}$ & $198.46^{\mathrm{G}}$ & $161.75^{\mathrm{F}}$ & $134.21^{\mathrm{EF}}$ \\
\hline \multicolumn{5}{|c|}{ Fermented-nano carrot pomace (\%) } \\
\hline 5 & $221.54^{\mathrm{I}}$ & $190.99^{\mathrm{I}}$ & $156.08^{\mathrm{H}}$ & $129.89^{\mathrm{GH}}$ \\
\hline 15 & $205.17^{\mathrm{J}}$ & $177.07^{\mathrm{J}}$ & $144.96^{\mathrm{K}}$ & $120.88^{\mathrm{J}}$ \\
\hline 25 & $188.07^{\mathrm{M}}$ & $171.84^{\mathrm{K}}$ & $153.29^{\mathrm{HI}}$ & $139.38^{\mathrm{CD}}$ \\
\hline \multicolumn{5}{|c|}{ Fermented-nano pomegranate peel (\%) } \\
\hline 5 & $221.27^{\mathrm{I}}$ & $194.89^{\mathrm{H}}$ & $164.73^{\mathrm{E}}$ & $142.11^{\mathrm{C}}$ \\
\hline 15 & $198.50^{\mathrm{L}}$ & $177.74^{\mathrm{J}}$ & $154.02^{\mathrm{HI}}$ & $136.23^{\mathrm{DE}}$ \\
\hline 25 & $160.94^{\circ}$ & $141.69^{\mathrm{L}}$ & $119.70^{\mathrm{L}}$ & $103.20^{\mathrm{K}}$ \\
\hline
\end{tabular}

Values in the same column followed by different letters are significantly different $(\mathrm{p}<0.05)$.

Egypt. J. Food. 47, No. 2 (2019) 


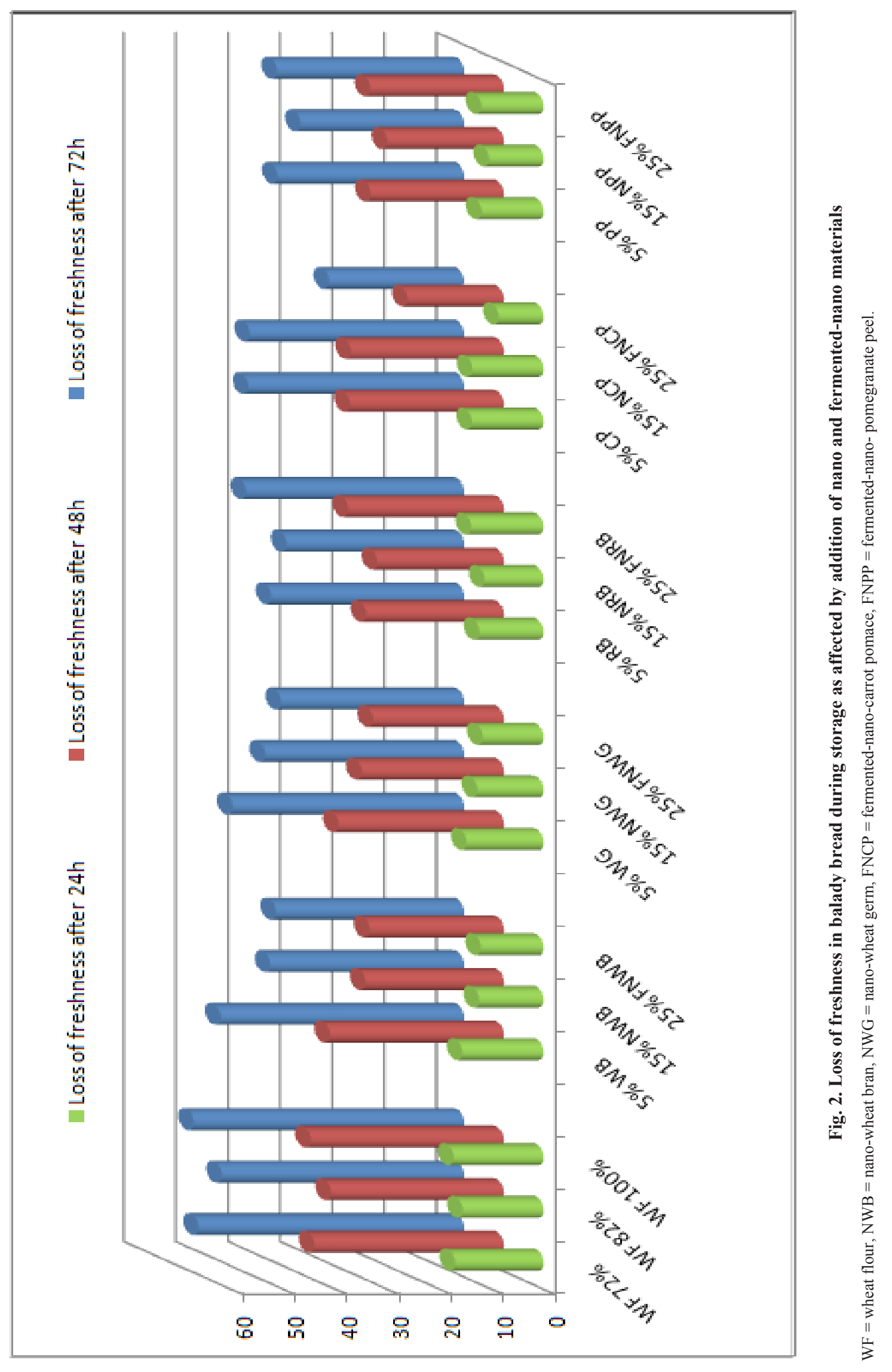

Egypt. J. Food. 47, No. 2 (2019) 


\section{References}

Belghith, L., Fendri, F., Chaari, F., Kallel, S., ZouariEllouzi, R., Ghorbel, S. and Besbes, A. (2016a) Pea and broad bean pods as a natural source of dietary fiber: The impact on texture and sensory properties of cake. Journal of Food Science, 81, C2360-C2366.

Belghith, L., Fendri, F., Chaari, M., Maaloul, F., Kallel, L. Abdelkafi, S. and Ellouz C. (2016b) Wheat bread enrichment by pea and broad bean pods fibers: Effect on dough rheology and bread quality. LWT - Food Science and Technology, 73, 584-591.

Ben Jeddou, K., Bouaziz, F., Zouari-Ellouzi, S., Chaari, F.; Ellouz-Chaabouni, S. and Ellouz-Ghorbel, R. (2017) Improvement of texture and sensory properties of cakes by addition of potato peel powder with high level of dietary fiber and protein. Food Chemistry, 217, 668-677.

Bhol, S., Lanka, D. and Bosco, S.J.D. (2016) Quality characteristics and antioxidant properties of breads incorporated with pomegranate whole fruit bagasse. Journal of Food Science and Technology, 53, 17171721.

Casuccio, G.S., Schlaegle, S.F., Lersch, T.L., Huffiman, G.B., Chen, Y. and Shah, N. (2004) Measurement of fine particulate matter using electron microscopy technique. Fuel Processing Technology, 85, 763779 .

Chau, C.F., Wang, Y.T. and Wen, Y.L. (2007) Different micronization methods significantly improve the functionality of carrot insoluble fiber. Food Chemistry, 100, 1402-1408.

Commission Internationale de l'Eclairage (CIE) (1976) Colorimetry: Official recommendations of the international commission on illumination. Publication CIE No.15 (E-1.3.1) Paris, France: Boreau Central de la CIE.

Derakhshan, Z., Ferrante, M., Tadi, M., Ansari, F., Heydari, A., Hosseini, M.S. and Sadrabad, E.K. (2018) Antioxidant activity and total phenolic content of ethanolic extract of pomegranate peels, juice and seeds. Food and Chemical Toxicology, 114, 108-111.

Dordevic, T.M., Siler-Marinkovic, S.S. and Dimitrijevic-Brankovic, S.I. (2010) Effect of fermentation on antioxidant properties of some cereals and pseudo cereals. Food Chemistry, 119, 957-963.

El-Farra, A.A., Khorshid, A.M., Mansour, S.M. and Elias, A.N. (1982) Studies on the possibility of supplementation of balady bread with various

Egypt. J. Food. 47, No. 2 (2019) commercial soy-products. Materials of $1^{\text {st }}$ Egyptian Conference on Bread Research, Cairo, pp. 9-23.

Eshak, N. S. (2016). Sensory evaluation and nutritional value of balady flat bread supplemented with banana peels as a natural source of dietary fiber. Annals of Agricultural Science, 61, 229-235.

Feili, R., Zzaman, W., Abdullah, W.N. and Yang, T.A. (2013) Physical and sensory analysis of high fiber bread incorporated with jackfruit rind flour. Food Science and Technology, 1, 30-36.

Gomez, M., Ronda, F., Blanco, C., Caballero, P. and Apesteguia, A. (2003) Effect of dietary fibre on dough rheology and bread quality. European Food Research Technology, 216, 51-56.

He, X. and Hwang, H. (2016) Nanotechnology in food science: functionality, applicability and safety assessment. Journal of Food and Drug Analysis, 24, 671-681.

He, X., Aker, W.G., Huang, M.J., Watts, J.D. and Hwang, H.M. (2015) Metal oxide nano-materials in nano-medicine: application in photodynamic therapy and potential toxicity. Curr. Top Med. Chem., 15, 1887-1900.

Heiniö, R.L., Noort, M.W.J., Katina, K., Alam, S.A., Sozer, N., de Kock, H.L. (2016) Sensory characteristics of whole grain and bran-rich cereal foods - a review. Trends in Food Science \& Technology, 47, 25-38.

Hemdane, S., Jacobs, P.J., Dornez, E., Verspreet, J., Delcour, J.A., Courtin, C.M. (2016) Wheat (Triticum aestivum L.) bran in bread making: A critical review. Comprehensive Reviews in Food Science and Food Safety, 15, 28-42.

Huang, Y.L., Sheu, F., Lee, M.H. and Chau, C. F. (2007) Effects of particle size reduction of insoluble fibres by micron technology on various caecal and faecal indices. Journal of the Science of Food and Agriculture, 88, 435-441.

Hwang, H.M., Ray, P.C., Yu, H. and He, X. (2012) Toxicology of designer/engineered metallic nanoparticles. In: Luque, R., Varma, R.S., Clark, J.H., Kraus, G.A., editors. Sustainable preparation of metal nano-particles: methods and applications, Cambridge, UK, Royal Society of Chemistry, P.190-212

Juszczak, L., Witczak, T., Ziobro, R., Korus, J., Cieślik, E. and Witczak, M. (2012) Effect of inulin on rheological and thermal properties of gluten-free dough. Carbohydrate Polymers, 90, 353-360. 
Kitterman, J.S. and Rubenthaler, G.L. (1971) Assessing the quality of early generation wheat selection with the micro AWRC test. Cereal Science Today, 16, 313-316.

Ktenioudaki A. and Gallagher E. (2012) Recent advances in the development of high-fibre baked products. Trends in Food Science \& Technology, 28, 4-14.

Majzoobi, M., Ghavi, F.S., Farahnaky, A., Jamalian, J. and Mesbahi, G. (2011) Effect of tomato pomace powder on the physicochemical properties of flat bread (Barbari bread). Journal of Food Processing and Preservation, 35, 247-256.

Martins, Z.E., Pinho, O. and Ferreira, I.M. (2017) Food industry by-products used as functional ingredients of bakery products. Trends in Food Science and Technology, 67, 105-128.

Martins, Z.E., Erben, M., Gallardo, A.E., Silva, R., Barbosa, I. and Pinho, O. (2015) Effect of spent yeast fortification on physical parameters, volatiles and sensorial characteristics of homemade bread. International Journal of Food Science \& Technology, 50, 1855-1863.

Mohammad, A. A., Yousif, E. I., Yaseen, A. A., Gdallah, M. G., Shouk, A. A. and Abdel Fatah, A. A. (2015) Physico-Chemical and functional properties of nano and fermented nano powders of some food plant By-products. Current Science International, 4, 503-514.

Moore, J., Cheng, Z., Hao, J., Guo, G., Liu, J., Lin, C. and Yu, L. (2007) Effects of solid-state yeast treatment on the antioxidant properties and protein and fiber compositions of common hard wheat bran. Journal of Agricultural and Food Chemistry, 55, 10173-10182.

Oliveira, M.S., Cipolatti, E.P., Furlong, E.B. and Soares, L.S. (2012) Phenolic compounds and antioxidant activity in fermented rice (Oryza sativa) bran. Ciência e Tecnologia de Alimentos, 32, 531-537.

Onipe, O.O., Jideani, A.I.O. and Beswa, D. (2015) Composition and functionality of wheat bran and its application in some cereal food products. International Journal of Food Science \& Technology, 50, 2509-2518.

Parvin, S., Elham, A., Shahin, Z. and Hosahalli, S.R. (2019) Ultrasound assisted extraction of bioactive compounds from pomegranate peel. LWT-Food Science and Technology, 101, 342-350.

Pathak, D., Majumdar, J., Raychaudhuri, U. and Chakraborty, R. (2016) Characterization of physicochemical properties in whole wheat bread after incorporation of ripe mango peel. Journal of Food Measurement and Characterization, 10, 554561.

Penella, J.M.S., Collar, C. and Haros, M. (2008) Effect of wheat bran and enzyme addition on dough functional performance and phytic acid levels in bread. Journal of Cereal Science, 48, 715-721.

Peressini, D. and Sensidoni, A. (2009) Effect of soluble dietary fibre addition on rheological and breadmaking properties of wheat doughs. Journal of Cereal Science, 49, 190-201.

Prabhu, A.A., Mrudula, C.M. and Rajesh, J. (2014) Effect of yeast fermentation on nutraceutical and antioxidant properties of rice bran. International Journal of Agricultural and Food Science, 4, 59-65.

Quiles, A., Campbell, G.M., Struck, S., Rohm, H. and Hernando, I. (2016) Fiber from fruit pomace: A review of applications in cereal-based products. Food Reviews International, 32, 1-20.

Rawat, N. and Indrani, D. (2015) Functional ingredients of wheat-based bakery, traditional, pasta, and other food products. Food Reviews International, 31, 125-146

Rosa, N.N., Barron, C., Gaiani, C., Dufour, C. and Micard, V. (2013) Ultra-fine grinding increases the antioxidant capacity of wheat bran. Journal of Cereal Science, 57, 84-90.

SAS System for Windows (Statistical Analysis System) (2008). Version 9.2. Cary, USA: SAS Institute Inc.

Schleibinger, M., Meyer, A. L., Afsar, N., Gyorgy N. A., Dicker, V., Schmitt, J. J. (2013) Impact of dietary fibers on moisture and crumb firmness of brown bread. Advnced Journal of Food Science and Technology, 5, 1281-1284.

Seleem, H. A., and Omran, A. A. (2014) Evaluation quality of one layer flat bread supplemented with beans and sorghum baked on hot metal surface. Food and Nutrition Sciences, 5, 2246-2256.

Sharma, K., Bansal, S., Mangal, M., Dixit, A.K., Gupta, R.K. and Mangal, A.K. (2016) Utilization of food processing by-products as dietary, functional, and novel fiber: A review. Critical Reviews in Food Science and Nutrition, 56, 1647-1661.

Shiau, S.Y., Wu, M.Y. and Liu, Y.L. (2015) The effect of pineapple core fiber on dough rheology and the quality of mantou. Journal of Food and Drug Analysis, 23, 493-500.

Egypt. J. Food. 47, No. 2 (2019) 
Srinivas, P.R., Philbert, M., Vu, T.Q., Huang, Q., Kokini, J.L., Soas, E. and Chen, H. (2010) Nanotechnology research: applications in nutritional sciences. $J$. Nutr., 140, 119-124.

Stoll, L., Flores, S.H. and Thys, R.C.S. (2015) Citrus peel fiber and its application as a fat substitute in loaf brad. Ciência Rural, 45, 567-573.

Wu, M.Y. and Shiau, S.Y. (2015) Effect of the amount and particle size of pineapple peel fiber on dough rheology and steam bread quality. Journal of Food Processing and Preservation, 39, 549-558.

Yamazaki, W.T. (1953) An alkaline water retention capacity test for the evaluation of cookie baking potentialities of soft winter wheat flours. Cereal Chemistry, 30, 242-246.
Yaseen, A.A., Shouk, A.A. and Selim M.M. (2007) Egyptian balady bread and biscuit quality of wheat and triticale flour blends. Polish Journal of Food and Nutritional Science, 57, 25-30.

Younas, A., Bhatti, M.S., Ahmed, A. and Randhawa, M.A. (2011) Effect of rice bran supplementation on cookie baking quality. Pakistan Journal of Agricultural Science, 48, 129-134.

Zhao, X.Y., Yang, Z.B., Cai, G.S. and Yang, Y.F. (2009) Effect of superfine grinding on properties of ginger powder. Journal of Food Engineering, 91, 217-222.

Zhu, K., Huang, S., Peng, W., Qian, H. and Zhou, H. (2010) Effect of ultrafine grinding on hydration and antioxidant properties of wheat bran dietary fiber. Food Research International, 43, 943-948.

$$
\begin{aligned}
& \text { تأثير المساحيق النانومترية لبعض النواتج الثانوية للتصنيع الغذائي على جودة الخبز البلدي } \\
& \text { المصري } \\
& \text { السيد ابراهيم يوسف'، عطية عبد الفتاح ياسين'، عبد الفتاح عبد الكريم عبد الفتاح'، عبد الحفيظ عبد اللطيف }
\end{aligned}
$$

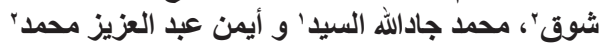

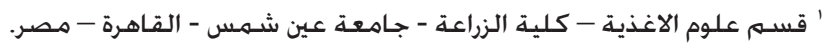

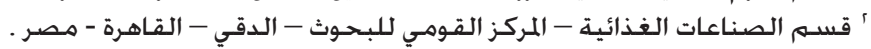

\footnotetext{
تعتبر تكنولوجيا النانو من التكنولوجيات الواعدة في تطوير طرق التصنيع الغذائي التقليدية، حيث يعتبر خَويل

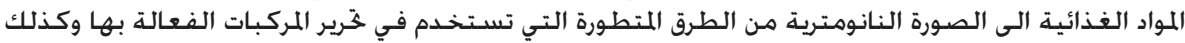

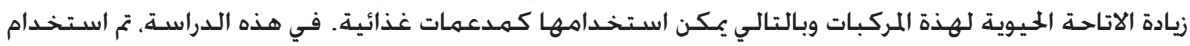

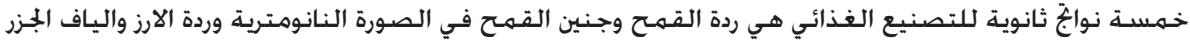

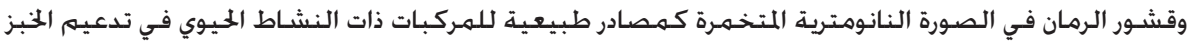

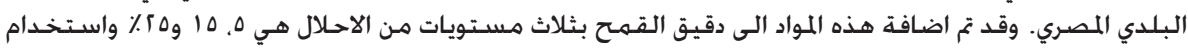

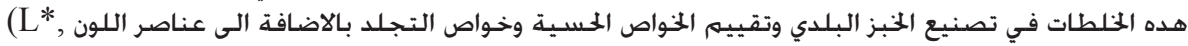

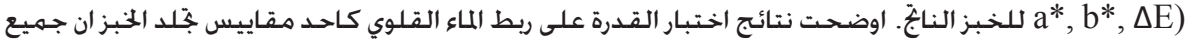

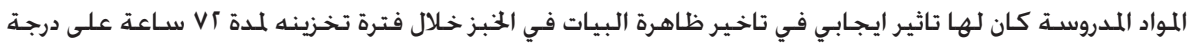

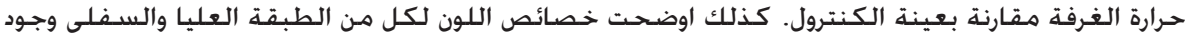

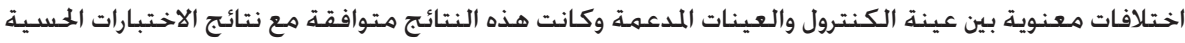

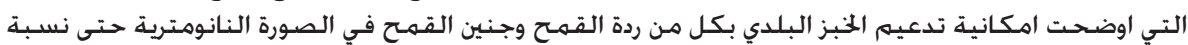

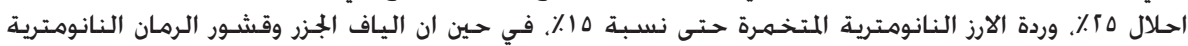

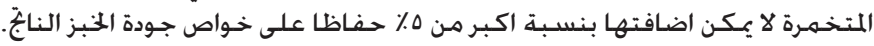

